\title{
Petrochemistry and Geotectonic Setting of Granitic Rocks in Aderan Area, S.W. Nigeria
}

\author{
C. T. Okonkwo ${ }^{1} \&$ I. O. Folorunso ${ }^{2}$ \\ ${ }^{1}$ Department of Applied Geology, Federal University of Technology, Akure, Nigeria \\ ${ }^{2}$ Department of Geology and Mineral Sciences, University of Ilorin, Ilorin, Nigeria \\ Correspondence: C. T. Okonkwo, Department of Applied Geology, Federal University of Technology, Akure, \\ Nigeria. Tel: 234-803-577-8090. E-mail: ctoo2003@yahoo.com
}

Received: September 27, 2012 Accepted: October 22, 2012 Online Published: December 5, 2012

doi:10.5539/jgg.v5n1p30 URL: http://dx.doi.org/10.5539/jgg.v5n1p30

\begin{abstract}
Aderan area, southwestern Nigeria is underlain by metaigneous and metasedimentary rocks which have been intruded by granitic rocks of probable Pan-African (ca. $600 \mathrm{Ma}$ ) age. Four types of granitic rocks have been identified in the area, including granitic gneisses, medium-grained granite, porphyritic granite and granodiorite. Geochemical analysis show that the rocks are largely calc-alkaline. The granodiorite is less siliceous and more calcic, and also contains less $\mathrm{Ba}, \mathrm{Nb}$ and $\mathrm{Rb}$, and more $\mathrm{Sr}, \mathrm{Ce}$ and $\mathrm{La}$ than the granites. Tectonically, the rocks classify as volcanic arc and syn-collisional and possibly late-to- post-collisional granitic rocks with respect to the Pan-African orogeny. Chemical characteristics indicate that these rocks were derived from partial melting of mafic to semi-pelitic (metasedimentary) crustal rocks under conditions of intermediate oxygen fugacity and activities of $\mathrm{H}_{2} \mathrm{O}$.
\end{abstract}

Keywords: granitic rocks, petrochemistry, tectonic setting, Pan-African orogeny, Aderan area

\section{Introduction}

The Nigerian Basement Complex forms the southern part of the Trans-Saharan mobile belt (Caby, 1989) of Neoproterozoic (750-500 Ma) age situated between the Archean-Paleoproterozoic blocks of the West African craton in the west, the Congo craton in the southeast ,and the East Saharan block in the northeast (Figure 1). The Nigerian basement complex comprises gneisses, migmatites and supracrustal sequences which have yielded relict Archean, Paleoproterozoic, as well as Neoproterozoic ages (Oversby, 1975; Rahaman, Emofurieta, \& Caen-Vachette,1983; Annor, 1995; Dada, 1998; Dada, Briqueu, \& Birck,1998; Ekwueme \& Kroner, 1993; Ferre, Caby, Peucat, Capdevilla, \& Monie, 1998).

The Neoproterozoic ( Pan-African) orogenic imprints in the Nigerian Basement Complex were characterized by high grade metamorphism, folding, faulting and widespread granite plutonism. These granitic rocks termed the "Older Granites" in Nigeria have been dated severally at 750-500Ma (van Breemen, Pidgeon, \& Bowden, 1977; Rahaman et al., 1983; Fitches, Ajibade, Egbuniwe, Holt, \& Wight, 1985; Ferre et al., 1998; Ekwueme \& Kroner, 1998). Similar granitic rocks have also been studied in various parts of the Nigerian basement complex- northern Nigeria (Olarewaju \& Rahaman, 1982), Jebba area (Okonkwo \& Winchester, 2004), Obudu Plateau, southeastern Nigeria (Ukwang \& Ekwueme, 2009), Kabba-Lokoja area (Ezepue \& Odigi, 1993), among others.

Granite magmatism is commonly associated with several tectonic settings and various stages during orogenic evolution (Pitcher, 1983; Pearce, Harris, \& Tindle, 1984; Whalen, Currie, \& Chappell, 1987; Maniar \& Piccoli, 1989; C. Frost, B. Frost, Chamberlain, \& Edwards, 1999). This paper considers the petrochemistry of the variably deformed and undeformed granitic rocks of Aderan area, southwestern Nigeria in terms of their origin and geotectonic setting. It is a contribution to the understanding of the geodynamic environment of the granitoid magmatism in this sector of the Nigerian basement complex. 


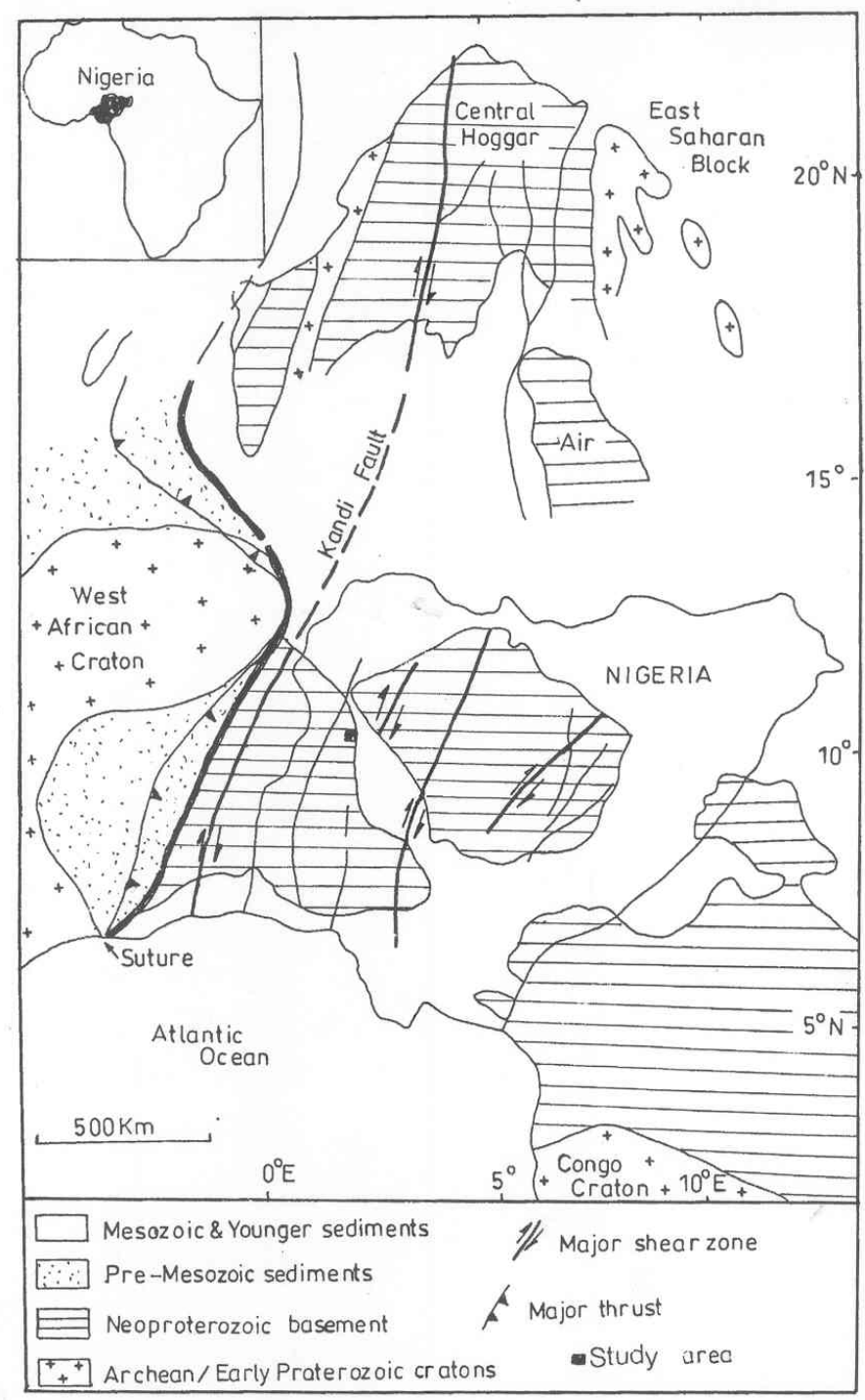

Figure 1. Index map showing the location of the study area in Nigeria between the West African craton and the Congo craton

\section{Geology of Aderan Area}

Aderan area is located at the northwestern margin of the southwestern sector of the Nigerian Basement Complex . The area is underlain by metaigneous and metasedimentary rocks which have subjected to polyphase deformation and metamorphism in the range of upper greenschist to amphibolite facies. These metamorphic rocks have intruded by granitic rocks of probable Neoproterozoic age.

In the area four lithostratigraphic units have identified (Figure 2). In the south, a belt of migmatitic gneisses characterized by concordant quartzofeldspathic bands associated with dark bands rich in biotitie, plagioclase and occasionally, hornblende. Locally, this rock type is intercalated with augen gneiss. The intercalated augen gneiss is similar to rocks dated at $c a 1900 \mathrm{Ma}$ in the Igbeti area $c a 50 \mathrm{~km}$ to the west. Two narrow N-S trending discontinuous belts of quartzites occurs in the central portion of the area. These quartzites have been locally cut by N-S trending, transcurrent shear zones. In the east are discontinuous belts of quartz-mica schists which locally contain thin psammitic bands probably reflecting original sedimentary, lithological variation. Also intercalated with the metamorphic rocks are thin, concordant bands of amphibolite. Intruding all these metamorrphic rocks are granitic rocks varying in composition from granodiorites to granites and pegmatites (Figure 2). 
Field evidence, including cross-cutting relations and presence of xenoliths of older rock types, indicate that the foliated (gneissic) granites are relatively, the oldest and the medium-grained grantes are older than the porphyritic granites while the relative age of the granodiorite is not yet known.

Rahaman et al. (1983) obtained a whole-rock $\mathrm{Rb} / \mathrm{Sr}$ isochron age of $617 \pm 37 \mathrm{Ma}$ for porphyritic granites of Igbeti area, about $50 \mathrm{~km}$ to the west which are similar to those of this study area.

Two episodes of ductile deformation and one of brittle - ductile deformation has affected the rocks of the area. The first two gave rise to the development of penetrative foliations in the metamorphic rocks and to the formation of asymmetric folds in the rocks. The third episode involved the formation of dextral, transcurrent shear zones which cut all the rocks including some of the Neoproterozoic granitoids.

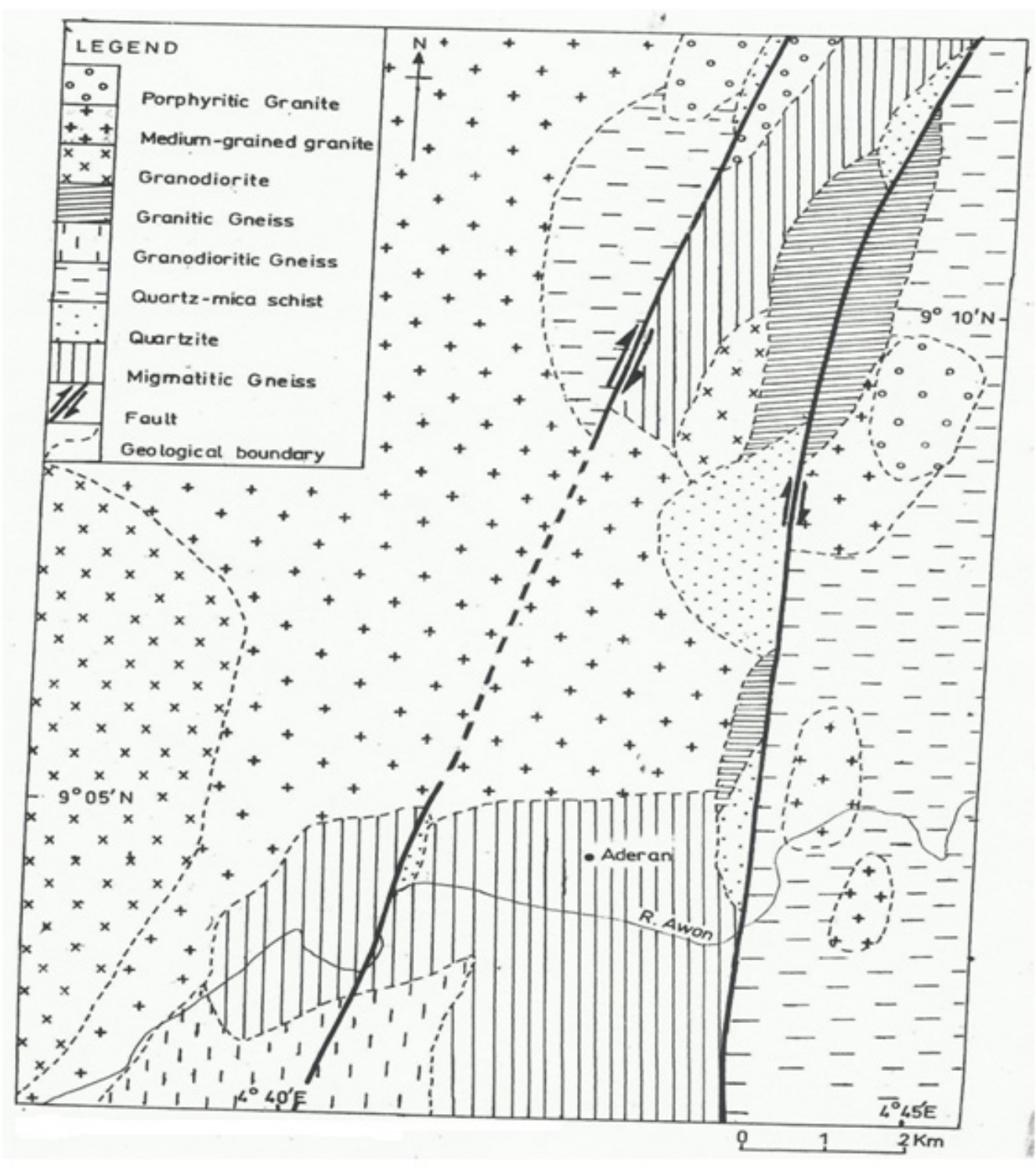

Figure 2. Geological map of Aderan area, southwestern Nigeria

\section{Petrography of the Granitic Rocks}

\subsection{Granodiorite}

This rock type occurs in the southwestern part of the area (Figure 2). It is dark grey and medium-grained. It consists of plagioclase (40-45\%), quartz (25-35\%) and biotite (12-15\%). Some of the plagioclase feldspar crystals are zoned have been partially sericitized while some biotite grains have been chloritized. Epidote, magnetite, apatite and zircon occur as accessory minerals. 


\subsection{Granitic Gneiss (Gneissose Granite)}

This rock type occurs mainly in the northeastern and central parts of the area close to the major shear zones (faults), (Figure 2). These rocks are foliated with strong planar preferred orientation of the constituent minerals especially, biotite $(5 \%)$, microcline $(40 \%)$, plagioclase $(10 \%)$, and quartz $(40 \%)$. Some varieties locally contain minor amounts of muscovite. Accessory minerals include titanite, zircon, and magnetite. Some sericite and chlorite also occur as partial replacements of plagioclase and biotite, respectively.

\subsection{Medium-grained Granite}

This rock type is the most widely distributed in the area. It is made of microcline, quartz, biotite and plagioclase feldspar with accessory amounts of titanite, zircon, apatite and magnetite. Sericite, epidote and chlorite occur as minor replacements of plagioclase and biotite, respectively.

\subsection{Porphyritic Granite}

This rock type occurs mainly in the northeastern part of the area. It contains phenocrysts of microcline-perthite (35-40\%) in a groundmass of plagioclase (20-25\%), quartz (30-35\%) and biotite (15\%). Locally, there have been partial replacements of plagioclase, biotite and hornblende by epidote, and chlorite, respectively. Accessory minerals include magnetite, zircon, apatite and titanite.

\section{Geochemistry}

Six samples of the granitic gneiss, four of the granodiorite, four samples of the medium-grained granite as well as two samples of the porphyritic granite were analysed for major and trace elements at Keele University, England and at the Technical University, Berlin, Germany by X-Ray Fluorescence Spectrometry. Analytical methods and precision have been described in Okonkwo and Winchester (1995). The major and trace elements compositions of the rocks are presented in Table 1.

Table 1. Chemical compositions of the granitic rocks of Aderan area

\begin{tabular}{|c|c|c|c|c|c|c|c|c|c|c|c|c|c|c|c|}
\hline \multirow{2}{*}{ Sample } & \multicolumn{2}{|c|}{ Porphyritic } & \multicolumn{4}{|c|}{ Medium-grained granites } & \multicolumn{4}{|c|}{ Granodiorites } & \multicolumn{5}{|c|}{ Granitic gneisses } \\
\hline & 36 & 37 & 48 & 49 & 76 & 77 & 60 & 61 & DG12 & 21 & NA1 & NA2 & DU2 & 42 & $3 \mathrm{~A}$ \\
\hline $\mathrm{SiO}_{2}$ & 64.8 & 62.1 & 72.9 & 68.86 & 71.99 & 69.66 & 66.5 & 67 & 66.2 & 66.8 & 75.53 & 73.3 & 76.1 & 72.35 & 72.78 \\
\hline $\mathrm{TiO}_{2}$ & 1.06 & 1.22 & 0.24 & 0.39 & 0.29 & 0.41 & 0.46 & 0.5 & 0.66 & 0.73 & 0.11 & 0.16 & 0.12 & 0.26 & 0.33 \\
\hline $\mathrm{Al}_{2} \mathrm{O}_{3}$ & 15 & 15.2 & 14.1 & 15.01 & 14.65 & 14.43 & 17 & 16 & 16.6 & 15.7 & 13.42 & 14.6 & 13.56 & 14.49 & 13.91 \\
\hline $\mathrm{Fe}_{2} \mathrm{O}_{3}$ & 5.96 & 6.6 & 1.83 & 2.85 & 1.91 & 2.66 & 3.74 & 3.9 & 4.13 & 4.89 & 0.88 & 1.01 & 0.85 & 1.8 & 2.12 \\
\hline $\mathrm{MnO}$ & 0.09 & 0.06 & 0.04 & 0.03 & 0.02 & 0.02 & 0.06 & 0 & 0.05 & 0.06 & 0.01 & 0.01 & 0.03 & 0.04 & 0.03 \\
\hline $\mathrm{MgO}$ & 1.59 & 2.66 & 0.23 & 0.61 & 0.51 & 1.13 & 0.96 & 1.5 & 1.32 & 1.16 & 0 & 0.3 & 0 & 0.3 & 0.34 \\
\hline $\mathrm{CaO}$ & 3.79 & 4.04 & 1.21 & 2.16 & 2.11 & 2.56 & 4.14 & 4.3 & 4.07 & 3.48 & 0.54 & 0.85 & 0.86 & 1.34 & 1.32 \\
\hline $\mathrm{Na}_{2} \mathrm{O}$ & 2.86 & 2.56 & 3.76 & 3 & 3.35 & 3.56 & 4.61 & 4.2 & 3.98 & 3.26 & 2.83 & 3.22 & 3.49 & 3.23 & 2.49 \\
\hline $\mathrm{K}_{2} \mathrm{O}$ & 3.87 & 4.81 & 5.08 & 6.2 & 4.56 & 4.97 & 1.49 & 1.9 & 1.92 & 3.36 & 5.68 & 6.33 & 4.36 & 5.78 & 5.58 \\
\hline $\mathrm{P}_{2} \mathrm{O}_{5}$ & 0.29 & 0.42 & 0.11 & 0.59 & 0.13 & 0.24 & 0.17 & 0.3 & 0.18 & 0.25 & 0.03 & 0.07 & 0.03 & 0.15 & 0.08 \\
\hline LOI & 0.39 & 0.15 & 0.37 & 0.64 & 0.33 & 0.38 & 0.63 & 0.8 & 0.43 & 0.36 & 0.23 & 0.49 & 0.46 & 0.58 & 0.42 \\
\hline Total & 99.7 & 99.7 & 99.9 & 100 & 99.83 & 100 & 99.8 & 100 & 99.5 & 100 & 99.25 & 100 & 99.86 & 100.3 & 99.4 \\
\hline $\mathrm{Ba}$ & 1325 & 1064 & 764 & 516 & 1878 & 1436 & 771 & 589 & 1334 & 1454 & 1779 & 1311 & 297 & 424 & 1397 \\
\hline $\mathrm{Cr}$ & 11 & 0 & 6 & 30 & 12 & 0 & 6 & 0 & 36 & 7 & 22 & 0 & 18 & 30 & 17 \\
\hline $\mathrm{Cu}$ & 29 & 19 & 5 & 10 & 13 & 10 & 25 & 20 & 15 & 16 & 20 & 15 & 0 & 10 & 22 \\
\hline $\mathrm{Ga}$ & 21 & 16 & 20 & 13 & 19 & 13 & 20 & 14 & 20 & 21 & 17 & 11 & 18 & 16 & 16 \\
\hline $\mathrm{Nb}$ & 24 & nd & 18 & nd & 4 & nd & 6 & nd & 9 & 16 & 2 & nd & 13 & nd & 2 \\
\hline $\mathrm{Ni}$ & 9 & 12 & 4 & 12 & 4 & 12 & 1 & 12 & 3 & 3 & 3 & 12 & 2 & 12 & 5 \\
\hline $\mathrm{Pb}$ & 19 & 15 & 46 & 28 & 21 & 15 & 4 & 15 & 13 & 13 & 34 & 22 & 55 & 29 & 17 \\
\hline $\mathrm{Rb}$ & 113 & 90 & 249 & 175 & 95 & 77 & 62 & 41 & 132 & 112 & 149 & 109 & 219 & 200 & 108 \\
\hline $\mathrm{Sr}$ & 458 & 344 & 207 & 144 & 901 & 705 & 1003 & 741 & 620 & 547 & 610 & 444 & 99 & 122 & 402 \\
\hline Th & 13 & 10 & 25 & 16 & 0 & 10 & 0 & 0 & 10 & 10 & 0 & 10 & 20 & 13.6 & 6 \\
\hline $\mathrm{V}$ & 96 & 87 & 13 & 12 & 38 & 41 & 46 & 33 & 79 & 64 & 23 & 17 & 3 & 10 & 30 \\
\hline $\mathrm{Y}$ & 48 & nd & 19 & nd & 8 & nd & 12 & nd & 11 & 21 & 0 & nd & 32 & nd & 3 \\
\hline $\mathrm{Zn}$ & 88 & 80 & 41 & 40 & 33 & 40 & 66 & 51 & 63 & 75 & 6 & 40 & 27 & 40 & 34 \\
\hline $\mathrm{Zr}$ & 302 & 247 & 154 & 99 & 113 & 94 & 269 & 208 & 241 & 240 & 87 & 80 & 81 & 74 & 183 \\
\hline $\mathrm{La}$ & 92 & nd & 37 & nd & 21 & nd & 51 & nd & 57 & 66 & 21 & nd & 17 & nd & 44 \\
\hline $\mathrm{Ce}$ & 179 & nd & 63 & nd & 7 & nd & 83 & nd & 36 & 126 & 14 & nd & 4 & nd & 69 \\
\hline $\mathrm{Nd}$ & 66 & nd & 34 & nd & 16 & nd & 38 & nd & 36 & 51 & 12 & nd & 10 & nd & 27 \\
\hline
\end{tabular}

nd - not determined. 


\subsection{Major Elements}

The granodiorite generally has the lowest concentrations of $\mathrm{SiO}_{2}$ and $\mathrm{K}_{2} \mathrm{O}$ and higher concentration of $\mathrm{CaO}$ compared with the other rock types. The granitic gneiss generally has lower concentrations of $\mathrm{Al}_{2} \mathrm{O}_{3}, \mathrm{Fe}_{2} \mathrm{O}_{3}$, $\mathrm{MgO}, \mathrm{CaO}$, and higher $\mathrm{SiO}_{2}$ compared with the other rock types (Table 1).

On the $\mathrm{Na}_{2} \mathrm{O}+\mathrm{K}_{2} \mathrm{O}$ versus $\mathrm{SiO}_{2}$ plot (Figure 3a) after Cox, Bell and Pankhurst (1979) the granitic gneisses and the medium-grained granites plot in the field of granite, while the granodiorites and the porphyritic granites plot in the field of quartz diorite (or granodiorite).

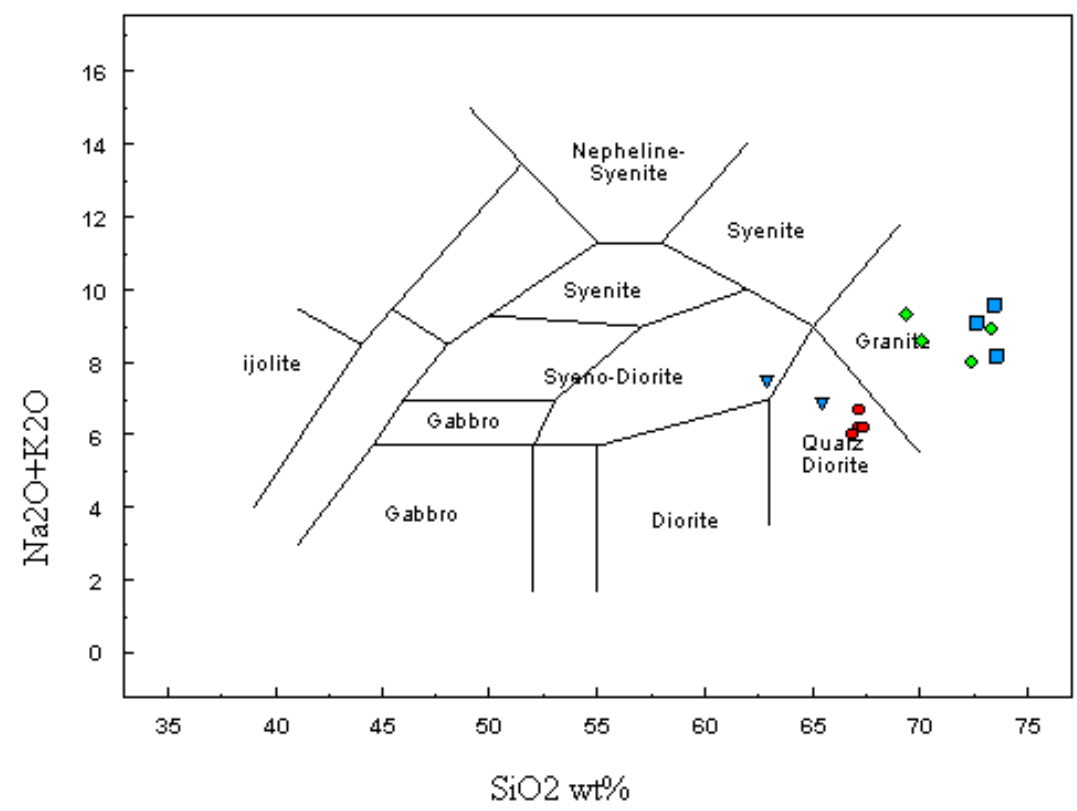

Figure 3a. $\mathrm{Na}_{2} \mathrm{O}+\mathrm{K}_{2} \mathrm{O}$ versus $\mathrm{SiO}_{2}$ diagram after Cox et al. (1979) showing the classification of the granitic rocks. Filled circles- granodiorite, squares- granitic gneiss, diamonds- medium- grained granite, triangles- porphyritic granite

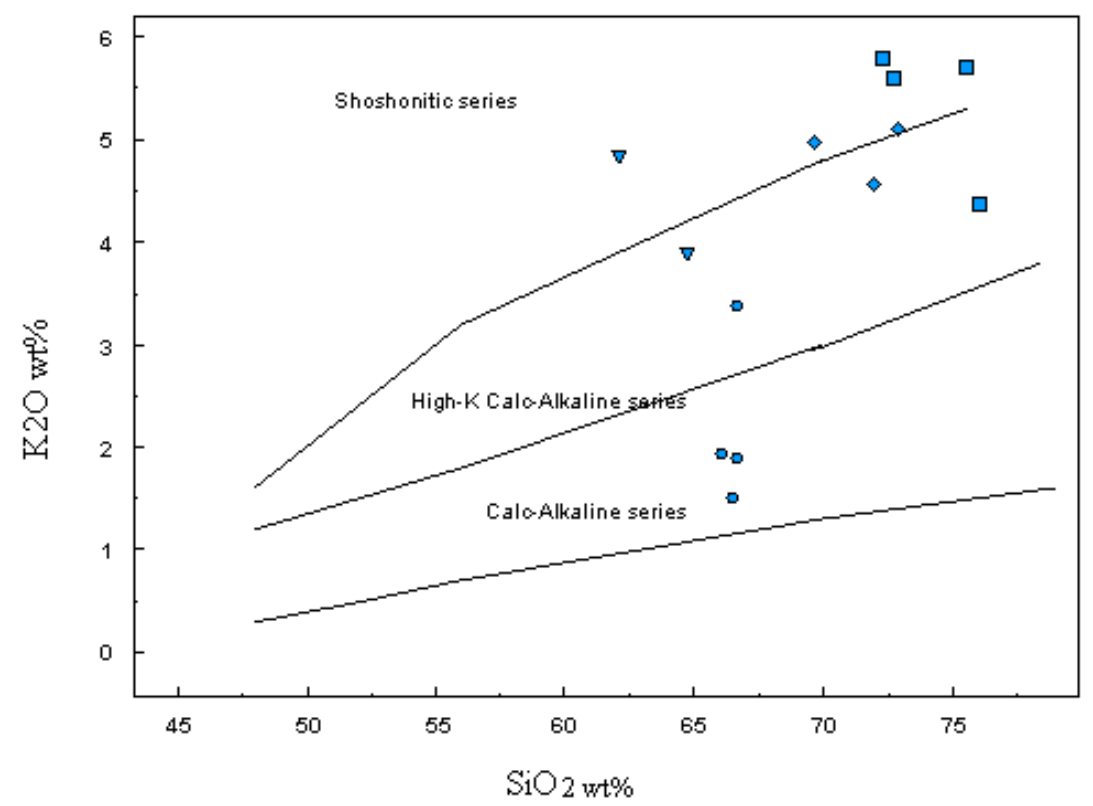

Figure 3b. $\mathrm{K}_{2} \mathrm{O}$ versus $\mathrm{SiO}_{2}$ diagram after Peccerillo and Taylor (1976) showing the classification of the granitic rocks. Symbols as in Figure 3a 
On the $\mathrm{K}_{2} \mathrm{O}$ versus $\mathrm{SiO}_{2}$ diagram (Figure 3b) after Peccerillo and Taylor (1976), the granitic gneisses, medium-granites and the porphyritic granites plot largely in the high-K calc-alkaline to shoshonitic fields while the granodiorite plots in the calc-alkaline, medium- $\mathrm{K}$ field. On the $\mathrm{Na}_{2} \mathrm{O}+\mathrm{K}_{2} \mathrm{O}-\mathrm{CaO}$ versus $\mathrm{SiO}_{2}$ diagram (Figure 3c) after B. Frost, Barnes, Collins, Arculus, Ellis and C. Frost (2001), the granitic gneisses, medium-grained granites and the porphyritic granites plot in the alkali-calcic to calc-alkali fields while the granodiorite plots in the calcic field . Also, on the plot of Fetotal/(Fetotal+MgO) against $\mathrm{SiO}_{2}$ (Figure 3d) after Frost et al. (2001), all the granitic rocks plot largely in a field overlapping the ferroan and magnesian rocks.

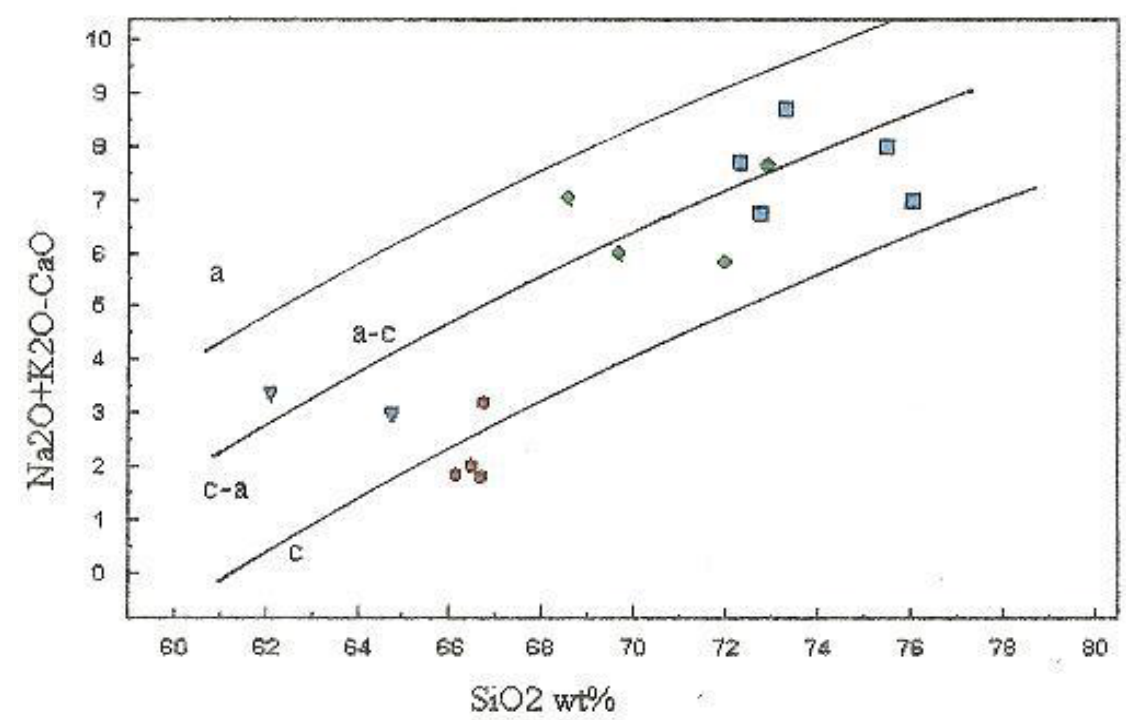

Figure 3c. $\mathrm{Na}_{2} \mathrm{O}+\mathrm{K}_{2} \mathrm{O}-\mathrm{CaO}$ versus $\mathrm{SiO}_{2}$ diagram after Frost et al. (2001) showing the classification of the rocks into a (alkalic), a-c (alkali-calcic) and c (calcic) groups. Symbols as in Figure 3a

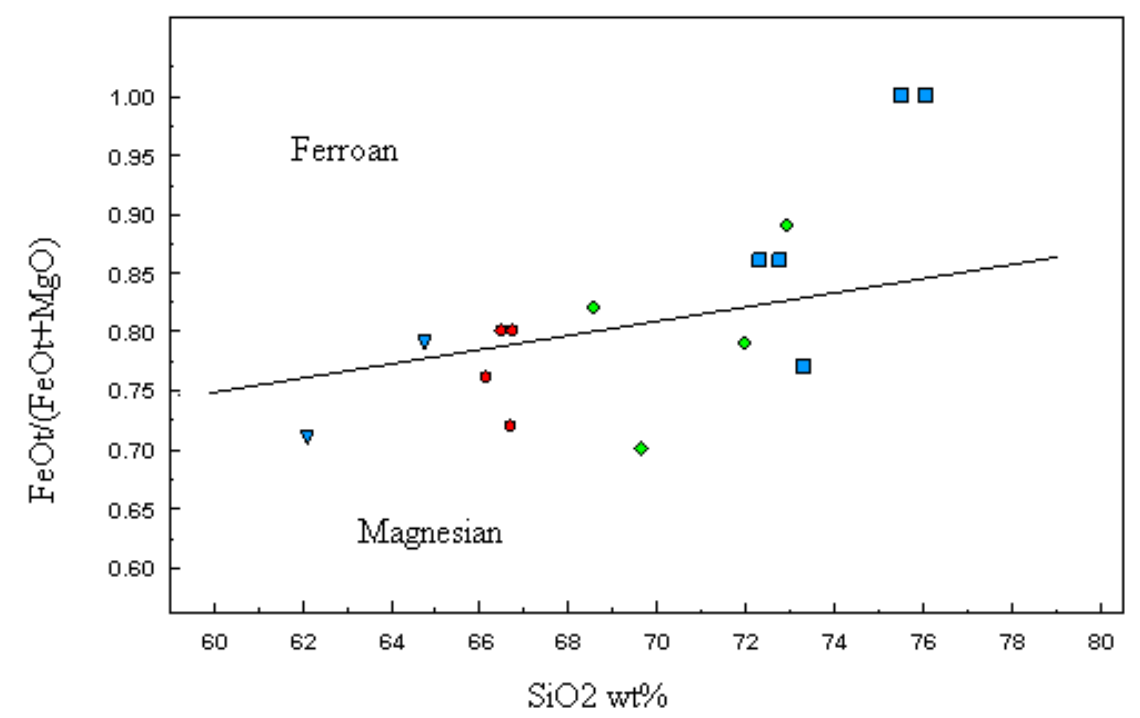

Figure 3d. FeOt/(FeOt+MgO) versus $\mathrm{SiO}_{2}$ diagram after Frost et al. (2001) showing the distribution of the granitic rocks with respect to the ferroan and magnesian fields. Symbols as in Figure $3 \mathrm{a}$

On the molecular $\mathrm{Al}_{2} \mathrm{O}_{3} /\left(\mathrm{Na}_{2} \mathrm{O}+\mathrm{K}_{2} \mathrm{O}\right)$ versus $\mathrm{Al}_{2} \mathrm{O}_{3} /\left(\mathrm{CaO}+\mathrm{Na}_{2} \mathrm{O}+\mathrm{K}_{2} \mathrm{O}\right)$ diagram (Figure $4 \mathrm{a}$ ) after $\mathrm{Maniar}$ and Piccoli (1989), the granitic gneisses plot in the peraluminous field, the granodiorites are slightly peraluminous, the porphyritic granites plot in the metaluminous field while the medium-grained granites are largely metaluminous. Also on the $\mathrm{A} / \mathrm{C}+\mathrm{N}+\mathrm{K}$ (ASI) versus $\mathrm{SiO}_{2}$ plot (Figure 4b) after White and Chappell (1977) the granitic rocks plot largely in the field of I-type granitoids except for most of the samples of the granitic gneiss which plot in the field of S-type granitoids. On the AFM diagram (Figure 4c), the granitic rocks follow a 
calc-alkaline trend with two clusters - a more alkaline cluster of granitic gneisses and medium-grained granites, and a more iron-rich cluster of the granodiorites and porphyritic granites.

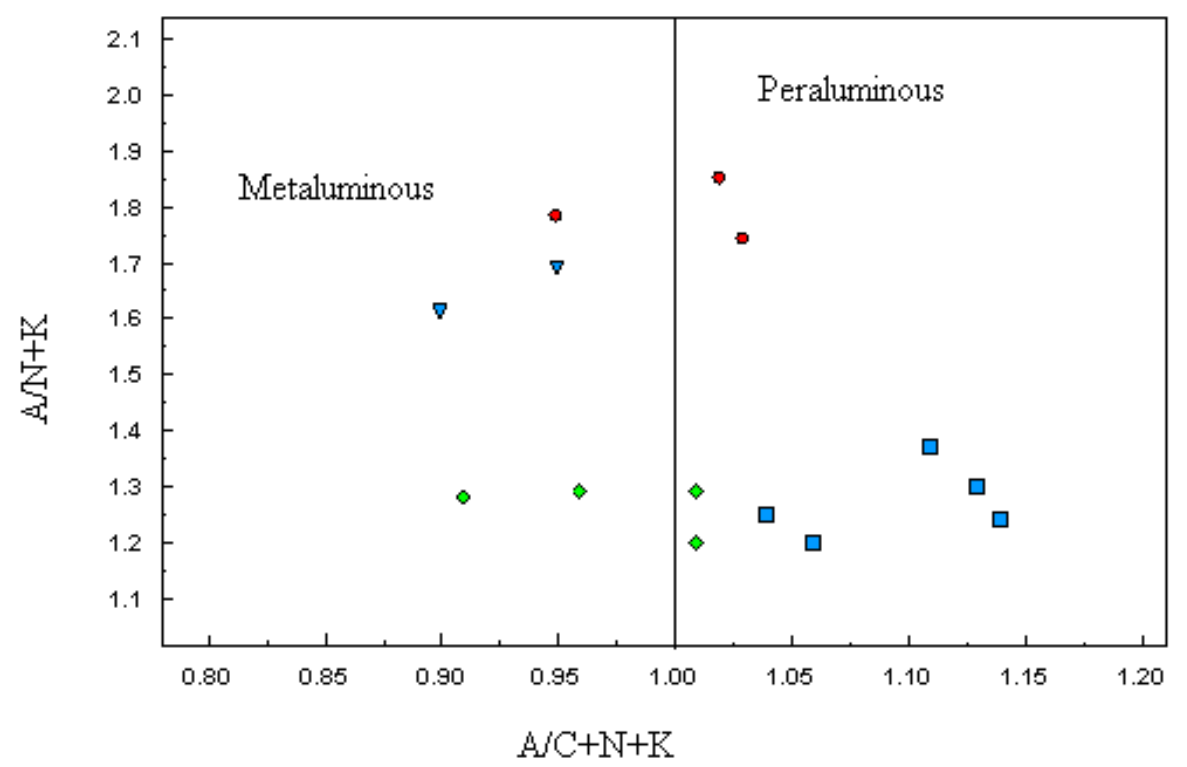

Figure 4a. Molecular $\mathrm{Al}_{2} \mathrm{O}_{3} / \mathrm{Na}_{2} \mathrm{O}+\mathrm{K}_{2} \mathrm{O}$ versus molecular $\mathrm{Al}_{2} \mathrm{O}_{3} / \mathrm{CaO}+\mathrm{Na}_{2} \mathrm{O}+\mathrm{K}_{2} \mathrm{O}$ diagram after Maniar and Piccoli (1989) showing the classification of the rocks into metalumnous and peraluminous fields. Symbols as in

Figure $3 \mathrm{a}$

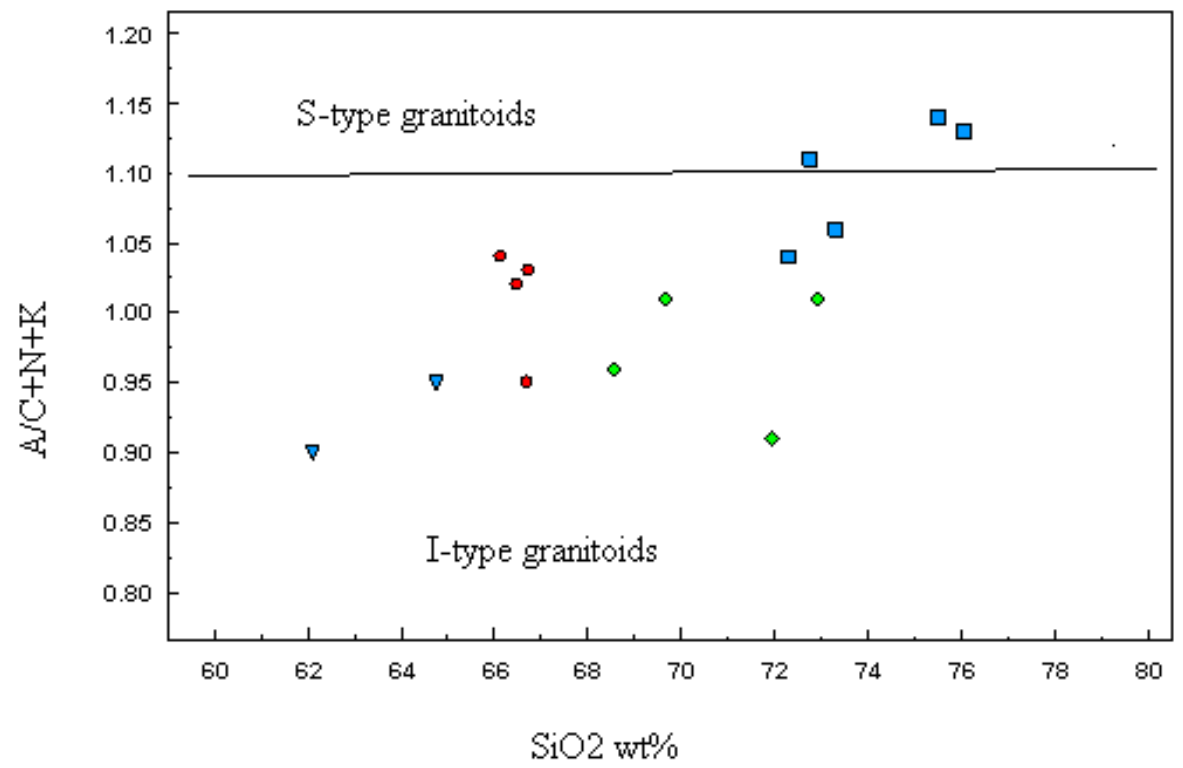

Figure 4b. Molecular $\mathrm{Al}_{2} \mathrm{O}_{3} / \mathrm{CaO}+\mathrm{Na}_{2} \mathrm{O}+\mathrm{K}_{2} \mathrm{O}$ versus $\mathrm{SiO}_{2}$ diagram showing the classification of the rocks into the fields of I-type and S-type granitoids. Symbols as in Figure 3a 


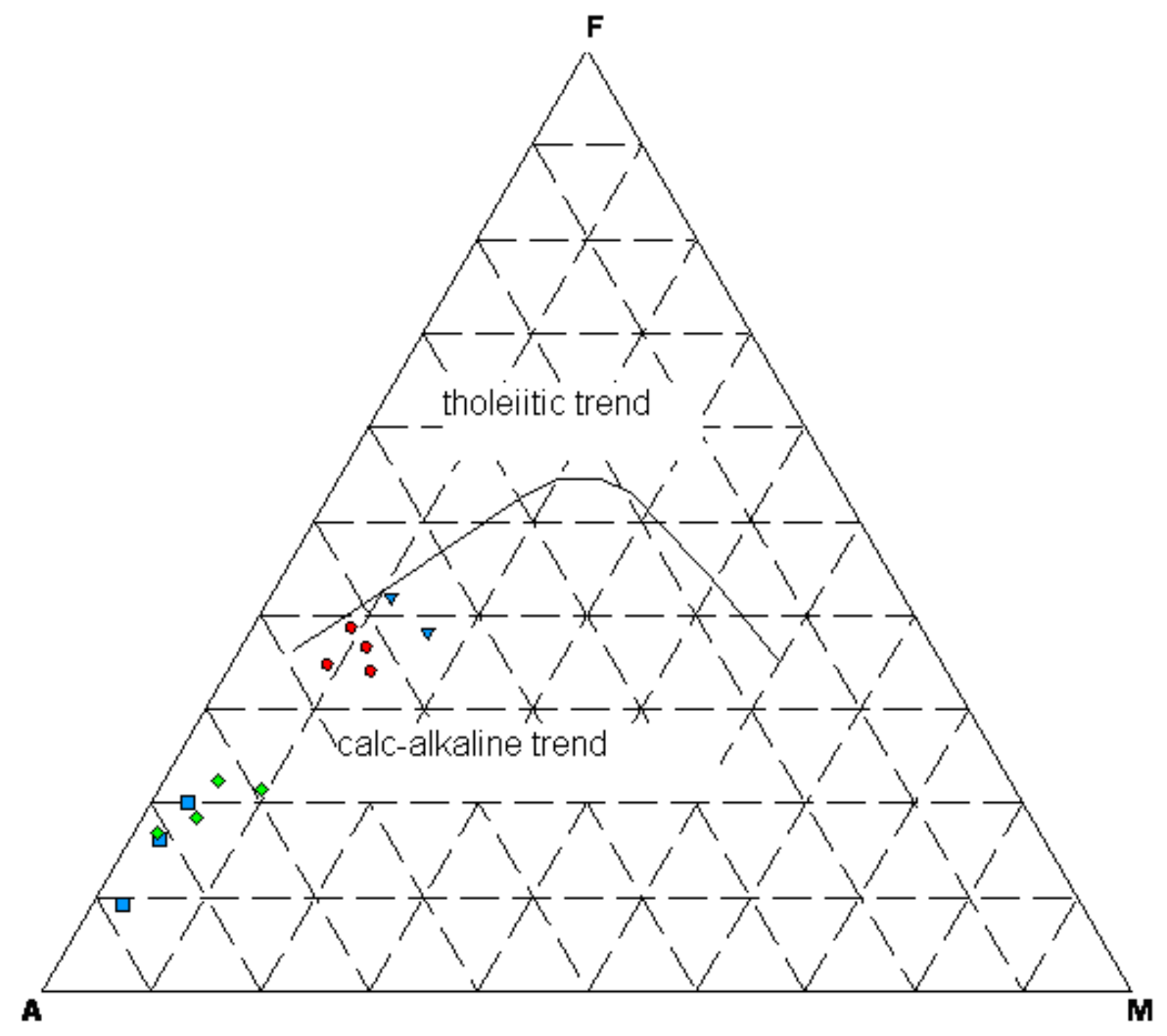

Figure 4c. AFM diagram showing the calc-alkaline trend of the rocks. Symbols as in Figure 3a

In Harker variation diagrams $\mathrm{SiO}_{2}$ shows very strong negative correlations with $\mathrm{Al}_{2} \mathrm{O}_{3}$, (Figure $5 \mathrm{a}$ ), $\mathrm{CaO}$ (Figure 5 b) and a positive correlation with $\mathrm{Na}_{2} \mathrm{O}$ (Figure 5c) indicating plagioclase fractionation; and a very strong negative correlation with $\mathrm{Fe}_{2} \mathrm{O}_{3}$ (Figure 5d) and $\mathrm{MgO}$ (Figure 5e) also suggesting pyroxene and hornblende fractionation. All these indicate the importance of fractional crystallization in the evolution of this magmatic suite. $\mathrm{SiO}_{2}$ also shows a good positive correlation with $\mathrm{K}_{2} \mathrm{O}$ (Figure $5 \mathrm{f}$ ) and with $\mathrm{Rb}$ (Figure $5 \mathrm{~g}$ ) also supporting the role of fractional crystallization. The granitic gneiss and the medium-grained granites are the more evolved of the magmatic suite.

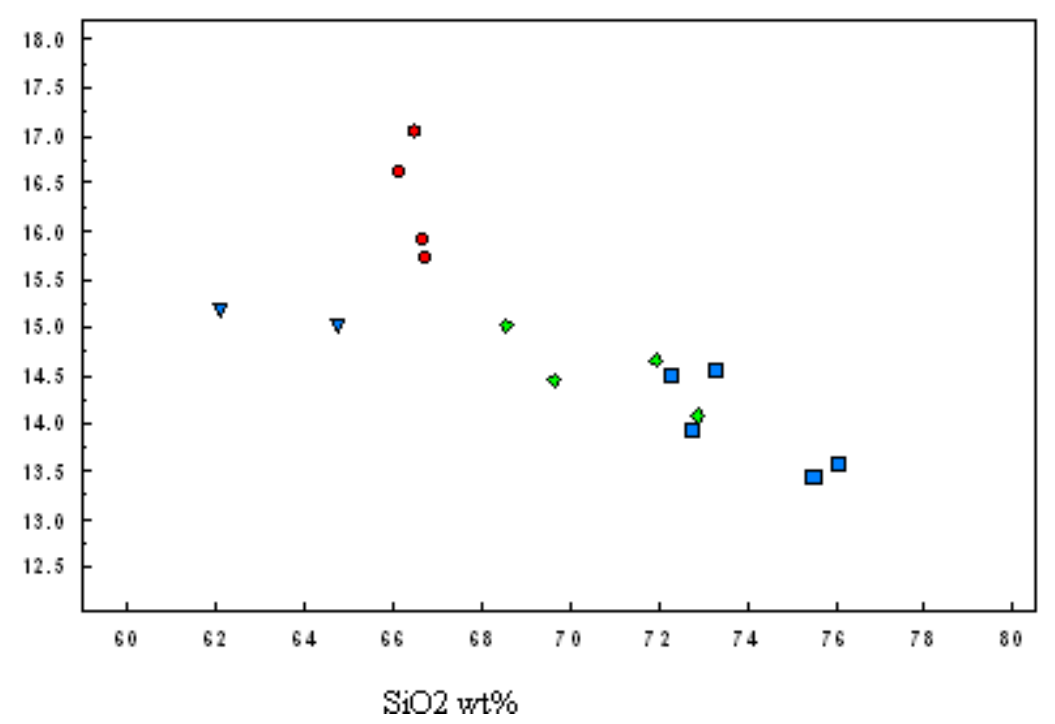

Figure 5a. Plot of $\mathrm{Al}_{2} \mathrm{O}_{3}$ versus $\mathrm{SiO}_{2}$ for the granitic rocks. Symbols as in Figure 3a 


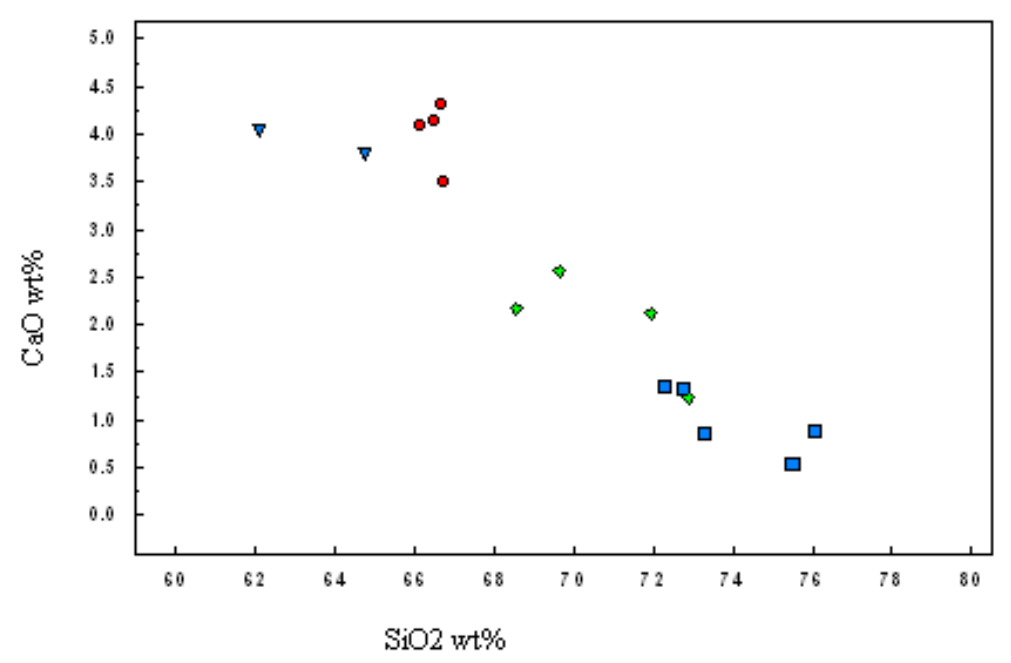

Figure 5b. Plot of $\mathrm{CaO}$ versus $\mathrm{SiO}_{2}$. Symbols as in Figure 3a

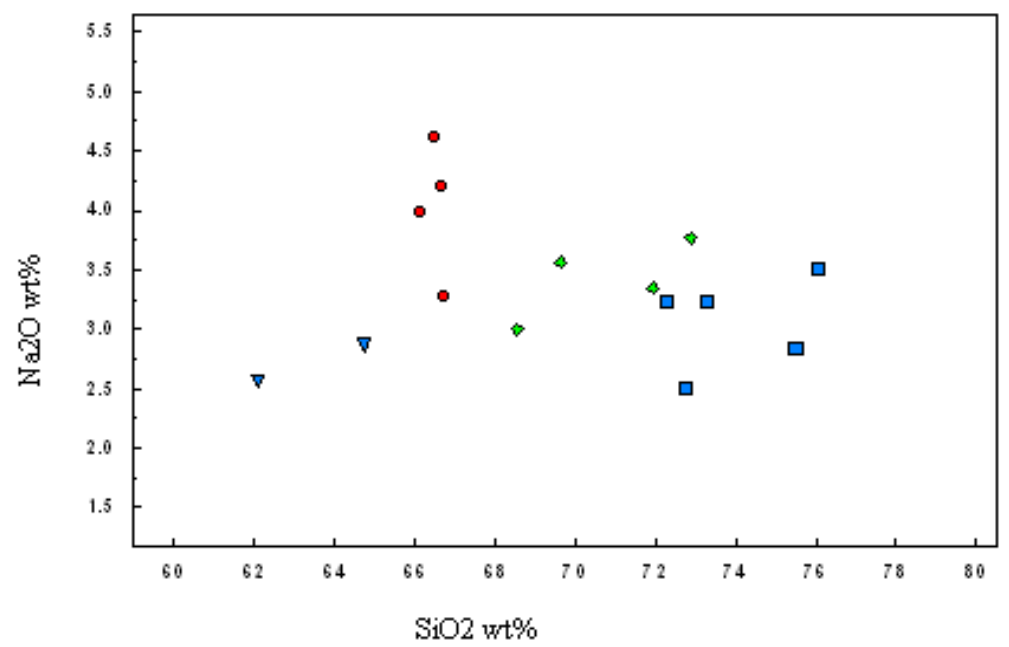

Figure 5c. Plot of $\mathrm{Na}_{2} \mathrm{O}_{3}$ versus $\mathrm{SiO}_{2}$. Symbols as in Figure 3a

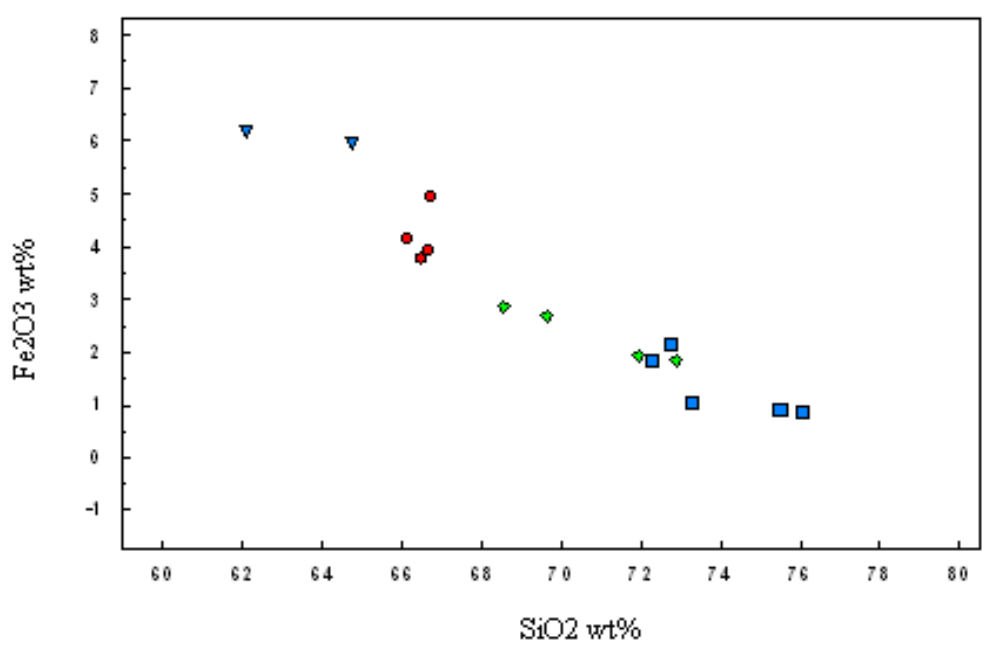

Figure 5d. Plot of $\mathrm{Fe}_{2} \mathrm{O}_{3}$ versus $\mathrm{SiO}_{2}$. Symbols as in Figure 3a 


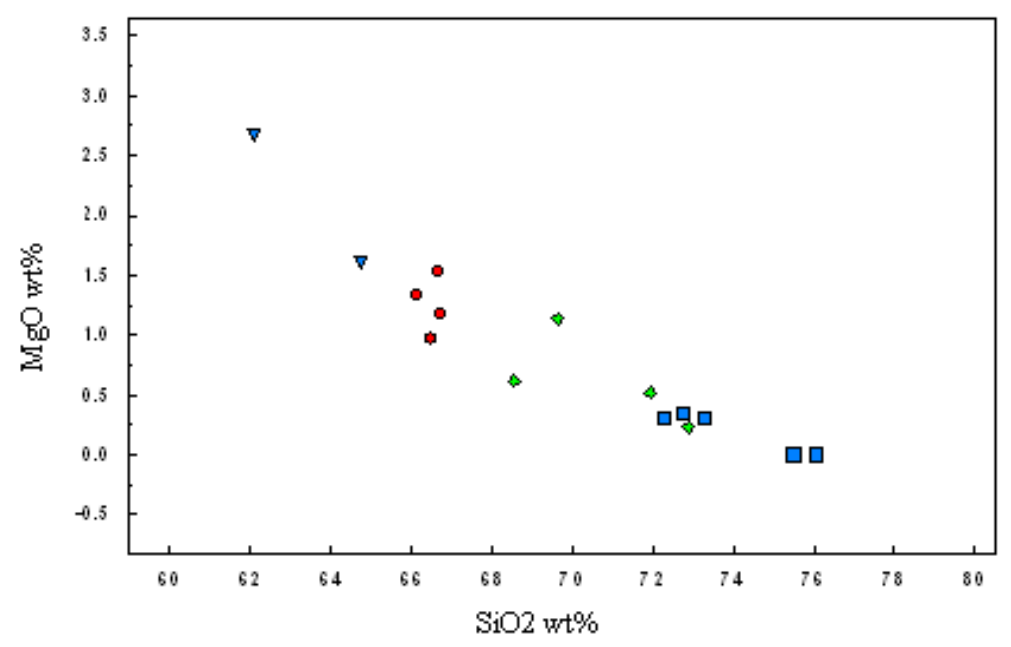

Figure 5e. Plot of $\mathrm{MgO}$ versus $\mathrm{SiO}_{2}$. Symbols as in Figure 3a

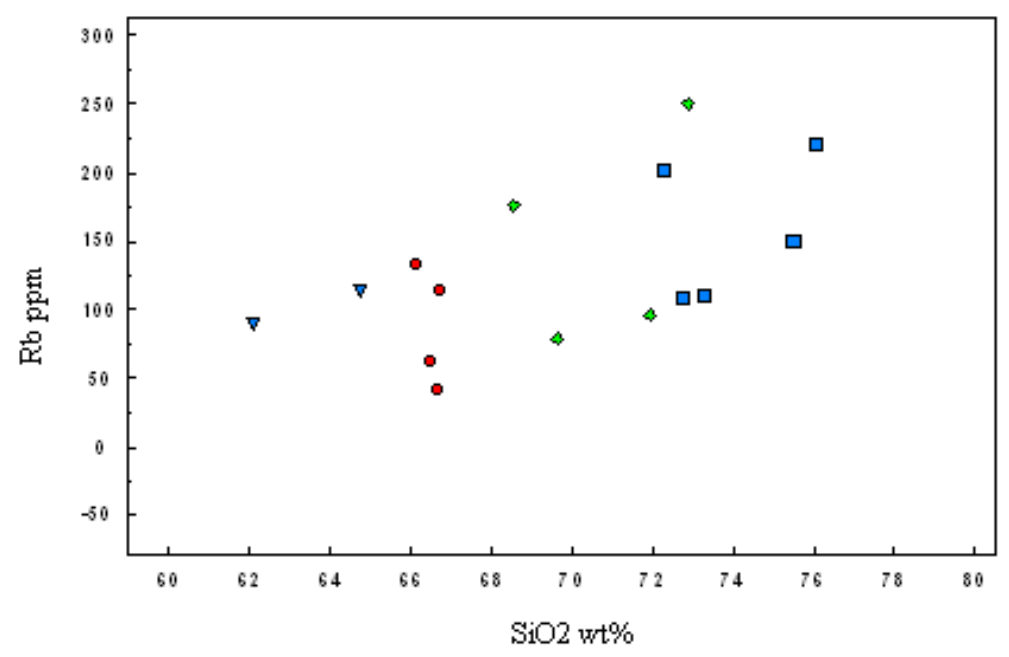

Figure 5g. Plot of $\mathrm{Rb}$ versus $\mathrm{SiO}_{2}$. Symbols as in Figure 3a

\subsection{Trace Elements}

The granodiorite generally has the highest concentrations of $\mathrm{Sr}$, La and $\mathrm{Ce}$ but lower $\mathrm{Rb}$ than the other rock types. On the other hand the granitic gneisses generally have the highest concentrations of $\mathrm{Rb}$ and lower values of the heavy rare-earth elements- $\mathrm{La}, \mathrm{Ce}$ and $\mathrm{Nd}$, compared with the other rock types (Table 1).

In the normalized multi-element spiderdiagram (primordial mantle of Wood et al., 1985, Figure 6a ), the granitic rocks show an enrichment in large ion lithophile (LIL) elements relative to the high field strength (HFS) elements as well as negative anomalies of $\mathrm{Nb}, \mathrm{Ce}, \mathrm{P}$ and $\mathrm{Ti}$. Some of the granitic gneisses and some of the medium-grained granites show some negative Ba anomaly. The element concentrations generally fall within the range for mature continental arcs (Brown, Thorpe, \& Webb, 1984). 


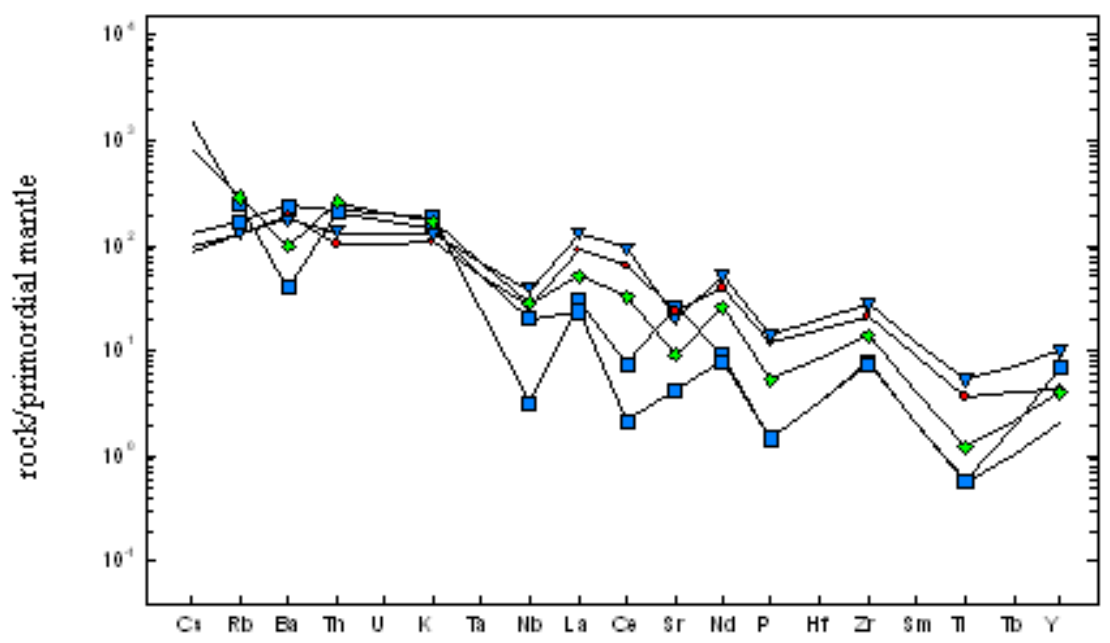

Figure 6a. Multi-element spiderdiagram of the granitic rocks. Normalizing values from Wooks et al. (1979).

Symbols as in Figure 3a

\subsection{Tectonic Classification}

On the $\mathrm{Nb}$ versus $\mathrm{Y}$ diagram (Figure $6 \mathrm{~b}$ ) after Pearce et al. (1984) the granitic rocks plot largely in the fields of Volcanic Arc and Syn-collisional Granites Also, on the Rb versus $\mathrm{Y}+\mathrm{Nb}$ diagram (Figure 6c) after Pearce et al. (1984) the rocks also plot largely in the field of Volcanic Arc Granites. On the $\mathrm{Rb} / \mathrm{Zr}$ versus $\mathrm{SiO}_{2}$ plot (Figure 6d) after Harris, Pearce, and Tindle (1986) these granitic rocks plot within the field of the Group III (Late to Post-Collisional) Granites and Volcanic-Arc Granites. It has been suggested Harris et al. (1986) that Group III is post-collisional and forms calc-alkaline suites with trace element characteristics similar to Volcanic-arc magmatism. They are believed to form like volcanic-arc magmas, from the LIL-enriched mantle wedge above subducted oceanic lithosphere which have probably been contaminated with melts from the lower crust. The crustal melts may have resulted from thermal relaxation in the lower crust and the mantle-derived magmas by adiabatic decompression in the upper mantle (Harris et al., 1986).

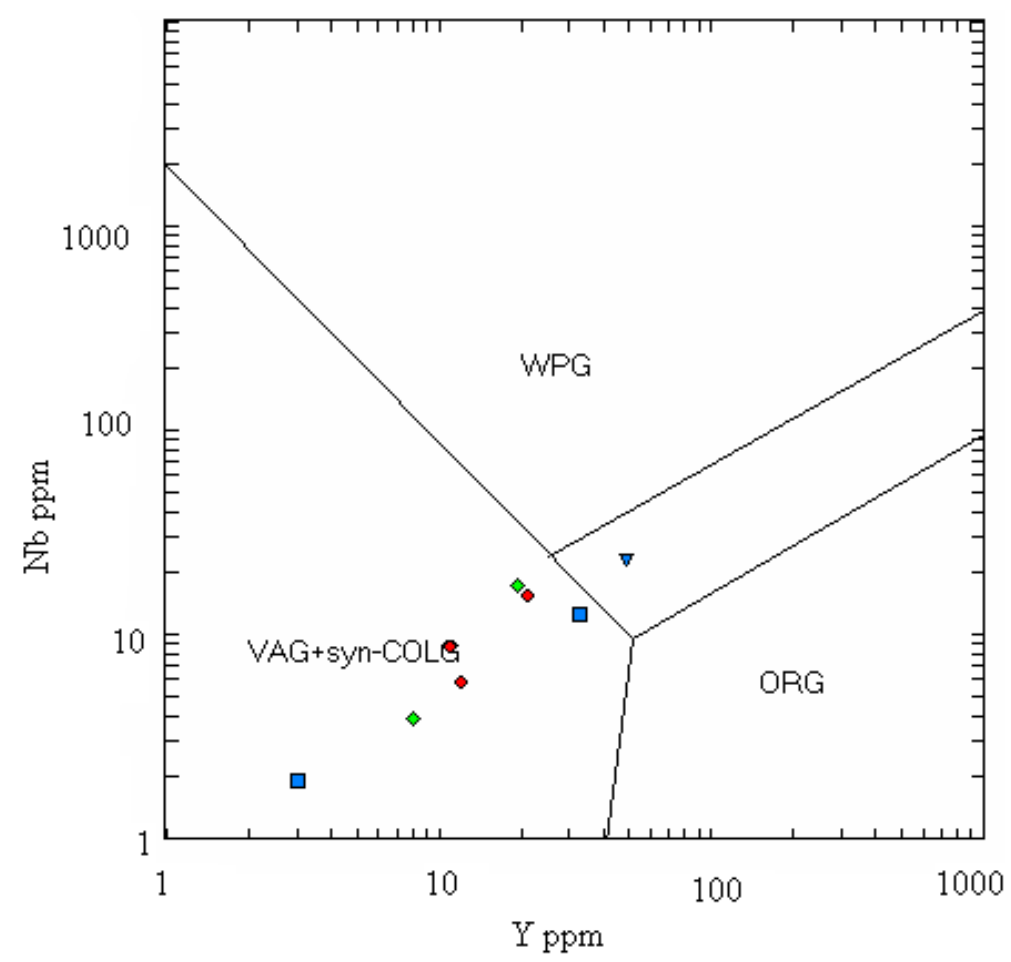

Figure 6b. $\mathrm{Nb}$ versus $\mathrm{Y}$ tectonic discrimination diagram after Pearce et al. (1984) showing the tectonic affinities of the rocks. Symbols as in Figure 3a 


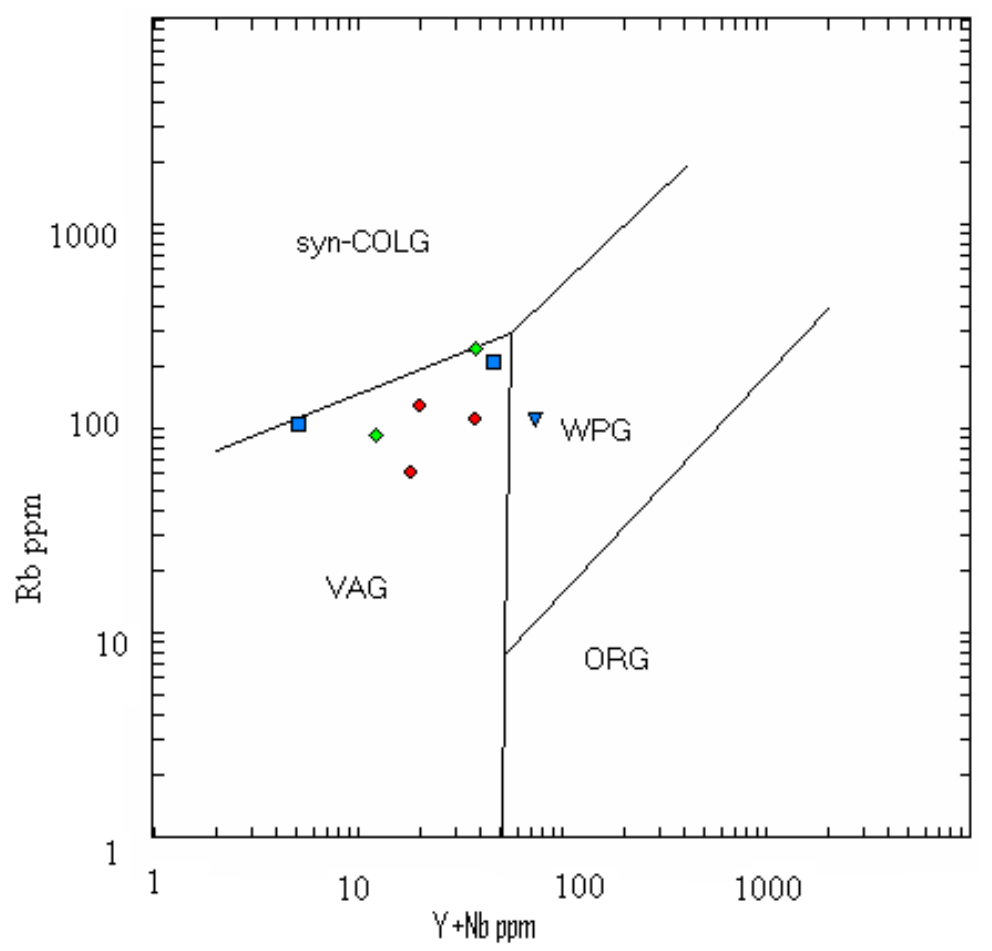

Figure $6 \mathrm{c} . \mathrm{Rb}$ versus $\mathrm{Y}+\mathrm{Nb}$ tectonic discrimination diagram after Pearce et al. (1984) showing the volcanic are affinity of the rocks. Symbols as in Figure 3a

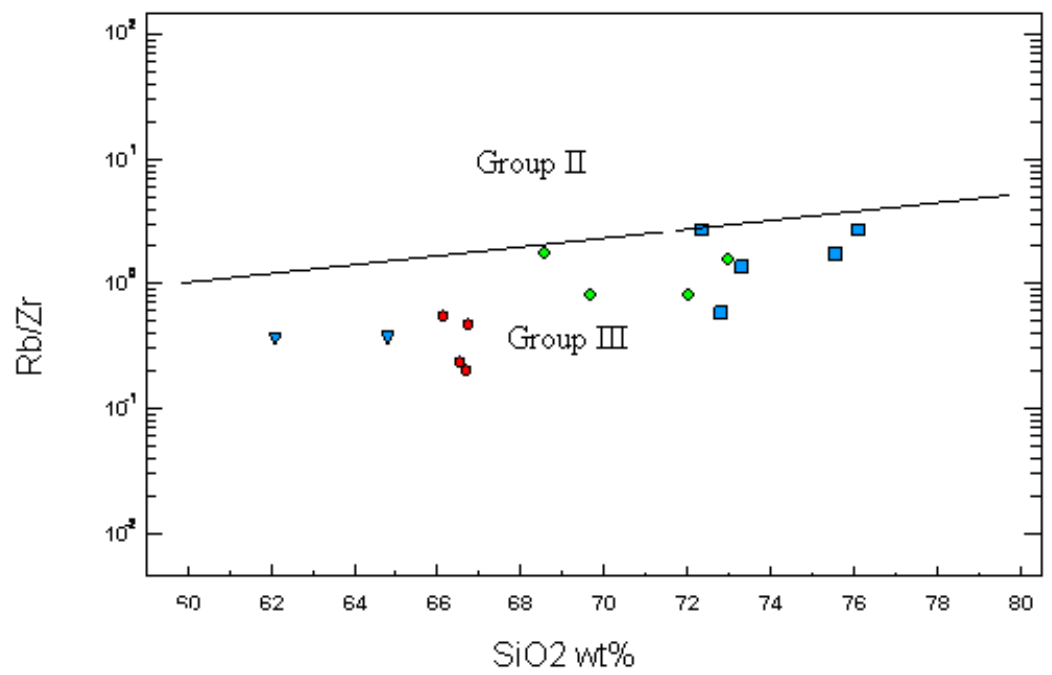

Figure 6d. $\mathrm{Zr}$ versus $\mathrm{SiO}_{2}$ diagram after Harris et al. (1986) indicating the Group III (post-collisional) affinity of the rocks. Volcanic arc granites also plot in this field. Symbols as in Figure 3a

\section{Discussion}

The granites of the Nigerian basement complex occur in the Neoproterozoic mobile belt formed during the convergence of lithospheric blocks during the Pan-African orogeny. This is borne out by their calc-alkaline characteristics as well as their affinity with volcanic arc and syn-collisional or post-collisonal granites. The early and deformed variety- the granitic gneiss- is probably syntectonic while the later medium-grained, granodiorite and porphyritic granite possibly mark the later stages- i.e. the late to post-collisional period.

The peraluminous nature of the granitic gneiss suggest derivation from partial melting of semipelitic metasedimentary rocks ( Holtz \& Johannes, 1991) and the slightly peraluminous of the granodiorites and the metaluminous nature of the porphyritic granite suggest derivation of their magmas from either melting of mafic 
rocks or ammphibolites (Ellis \& Thompson, 1986; Patino Douce, 1999). The slightly metaluminous nature of the granodiorite may also be due to some assimilation of of metasedimentary material by their magma (Frost et al., 1999).

Ferroan (Fe-enriched) granites are closely associated with conditions of limited availability of $\mathrm{H}_{2} \mathrm{O}$ and low oxygen fugacity during partial melting of their source rocks (Frost et al., 2001) as well as the crystallization of anhydrous silicates. On the other hand, magnesian granites are associated with relatively hydrous magmas and oxidizing differentiation trends (Frost \& Lindsley, 1991). It would therefore appear that these granitic rocks evolved under largely intermediate conditions with respect to these parameters.

These granitic rocks in Aderan area are similar petrochemically to the granitic suite documented in the Jebba area to the east by Okonkwo and Winchester (2004).

The porphyritic granites are also similar petrologically and chemically to the coarse, porphyritic granites of Igbeti area, southwestern Nigeria dated $617 \pm 37$ Ma (Rahaman et al., 1983). In northeastern Nigeria, Ferre et al. (2002) recognized two granite suites which intruded the area during the Pan-African orogeny- early, peraluminous, biotite-muscovite granites dated ca $605 \mathrm{Ma}$ and younger, porphyritic, metaluminous, hornblende-biotite granites emplaced at ca 580 Ma. These suites thus correspond petrographically and geochemically to the two main types of granites observed in the Aderan area.

In southeast Nigeria, Ukwang and Ekwueme (2009) have documented granitic rocks in Obudu Plateau with volcanic arc and syncollisional affinity emplaced with regard to the Pan-African orogeny

In the northeast of Nigeria, Ferre et al. (1998) have described hypersthene-bearing monzogranitic and quartz-monzonitic rocks of Neoprterozoic age with ferro-potassic transalkaline and metaluminous characteristics which have affinity with within-plate or post-collisional granites. They assigned these rocks to the post-collisional stage of the Pan-African orogeny.

\section{Conclusions}

The foliated granitic gneisses of Aderan area are calc-alkaline, probably syn-collisional peraluminous granites emplaced during the Pan-African orogeny. The more calcic granodiorites and the largely shoshonitic, alkali-calcic porphyritic granites are probably late- to post-collisional with respect to the Pan-African orogeny.

The predominance of these granitoid rocks in the Aderan area indicate their emplacement in mature continental arcs associated with thick continental crust probably during the Pan-African orogeny.

\section{Acknowledgements}

We thank Prof. J. A. Winchester and D. Emley (Keele University, England) and O. Adekeye (Technical University, Berlin) for assistance with the chemical analysis of the rock samples. Fieldwork was partly supported by grants from the Senate Research Fund of the University of Ilorin, Nigeria. We appreciate the helpful comments of the anonymous referee which have contributed to the improvement of the original manuscript.

\section{References}

Annor, A. E. (1995). U-Pb zircon age for Kabba-Okene granodiorite gneiss: implications for Nigeria's basement chronology. Africa Geoscience Review, 2, 101-105.

Brown, G. C., Thorpe, R. S., \& Webb, P. C. (1984). The geochemical characteristics of granitoids in contrasting arcs and comments on magma sources. Journal of the Geological Society of London, 141, 413-426. http://dx.doi.org/10.1144/gsjgs.141.3.0413

Caby, R. (1989). Precambrian terranes of the Benin-Nigeria and Northeast Brazil and the late Proterozoic South Atlantic fit. Geological Society of America Special Paper, 230, 145-158.

Cox, K. G., Bell, J. D., \&Pankhurst, R. J. (1979). The Interpretation of Igneous Rocks. London: George Allen \& Unwin.

Dada, S. S. (1998). Crust-forming ages and Proterozoic crustal evolution in Nigeria: a reappraisal of current interpretations. Precambrian Research, 87, 65-74. http://dx.doi.org/10.1016/S0301-9268(97)00054-5

Dada, S. S., Briqueu, L., \& Birck, J. L. (1998). Primordial crustal growth in northern Nigeria: Preliminary Rb-Sr and Sm-Nd constraints from Kaduna migmatite-gneiss complex. Journal of Mining and Geology, 34, 1-6.

Ekwueme, B. N., \& Kroner, A. (1998). Single zircon evaporation ages from the Oban Massif, southeastern Nigeria. Journal of African Earth Sciences, 26, 195-205. http://dx.doi.org/10.1016/S0899-5362(98)00005-0 
Ellis, D. J., \& Thompson, A. B. (1986). Subsolidus and partial melting reactions in the quartz-excess $\mathrm{CaO}+$ $\mathrm{MgO}+\mathrm{Al}_{2} \mathrm{O}_{3}+\mathrm{SiO}_{2}+\mathrm{H}_{2} \mathrm{O}$ system under water-excess water-deficient conditions to $10 \mathrm{~kb}$ : some implications for the origin of Peraluminous melts from mafic rocks. Journal of Petrology, 27, 91-121. http://dx.doi.org/10.1093/petrology/27.1.91

Ezepue, M. C., \& Odigi, M. I. (1993). Petrology and geochemistry of monzodiorites, granodiorites and granites from the Precambrian Terrain between Kabba and Lokoja, SW Nigeria. Journal of mining and Geology, 29, 27-39.

Ferre, E. C., Caby, R., Peucat, J. J., Capdevila, I. R., \& Monie, P. (1998). Pan-African post-collisional ferro-potassic granite and quartz-monzonite plutons of Eastern Nigeria. Lithos, 45, 255-278. http://dx.doi.org/10.1016/S0024-4937(98)00035-8

Ferre, E. C., Gleizes, G., \& Caby, R. (2002). Obliquely convergent tectonics and Granite emplacement in the Trans-Saharan belt of Eastern Nigeria: a synthesis. Precambrian Research, 114, 199-219. http://dx.doi.org/10.1016/S0301-9268(01)002261-1

Fitches, E. C., Ajibade, A. C., Egbuniwe, I. G., Holt, R. W., \& Wright, J. B. (1985). Late Proterozoic schist belts and plutonism in N W Nigeria. Journal of Geological Society of London, 142, 312-337. http://dx.doi.org/10.1144/gsjgs.142.2.0319

Frost , C. D., \& Frost, B. R. (1997). High-K, iron-enriched rapakivi-type granites: the tholeiite connection. Geology, 25, 647-650. http://dx.doi.org/10.1130/0091-7613(1997)025<0647:RRTGTT>2.3.CO;2

Frost, C. D., Frost. B. R., Chamberlain, K. R., \& Edwards, B. R. (1999). Petrogenesis of the 1.43 Ga Sherman batholith, SE Wyoming: a reduced rapakivi-type anorogenic granite. Journal of Petrology, 40, 1771-1802. http://dx.doi.org/10.1093/petroj/40.12.1771

Frost, B. R., Barnes, C. G., Collins, W. J., Arculus, R. J., Ellis, D. J., \& Frost, C. D. (2001). A geochemical classification for granitic rocks. Journal of Petrology, 42, 2033-2048. http://dx.doi.org/10.1093/petrology/42.11.2033

Frost, B. R., \& Lindsley, D. H. (1991). The occurrence of Fe-Ti oxides in igneous rocks. In D. H. Lindsley (Ed.), Oxide Minerals: Petrologic and Magnetic Significance. Mineralogical Society of America, Reviews in Mineralogy, 25, 433-486.

Harris, N. B. W., Pearce, J. A., \& Tindle, A. G. (1986). Geochemical characteristics of collision zone magmatism. In M. P. Coward, \& A. C. Ries (Eds.), Collision Tectonics (pp. 67-81). Geological Society of London Special Publication 19. http://dx.doi.org/10.10.1144/GSL.SP.1986.019.01.04

Holtz, F., \& Johannes, W. (1991). Genesis of peraluminous granites I. Experimental investigation of melt compositions at 3 and $5 \mathrm{~kb}$ and various $\mathrm{H}_{2} \mathrm{O}$ activities. Journal of Petrology, 32, 935-958. http://dx.doi.org/10.1093/petrology/32.5.935

Maniar, P. D., \& Piccoli, P. M. (1989). Tectonic discrimination of granitoids. Geological Society of America Bulletin, 101, 635-643. http://dx.doi.org/10.1130/0016-76006(1989)101<0635:TDOG>2.3.CO;2

Okonkwo, C. T., \& Winchester, J. A. (2004). Geochemistry of granitic rocks in Jebba area, southwestern Nigeria. Journal of Mining and Geology, 40, 95-100.

Olarewaju, V. O., \& Rahaman, M. A. (1982). Petrology and geochemistry of Older Granites from some parts of northern Nigeria. Journal of Mining and Geology, 18, 16-28.

Patino Douce, A. E. (1999). What do experiments tell us about the relative contributions of crust and mantle to the origin of granitic magma? In A. Castro, C. Fernandez, \& J. L. Virgneresse (Eds.), Understanding granites: Intergrating New and Classical Techniques (pp. 55-75). Geological Society of London, Special Publication 168. http://dx.doi.org/10.1144/GSL.SP.1999.168.01.05

Pearce, J. A., Harris, N. B. W., \& Tindle, A. G. (1984). Trace element discrimination diagrams for the tectonic classification of granitic rocks. Journal of Petrology, 25, 956-983. http://dx.doi.org/10.1093/petrology/25.4.956

Peccerillo, A., \& Taylor, S. R. (1976). Geochemistry of Eocene calc-alkaline volcanic rocks from the Kastamonu area, northern Turkey. Contributions to Mineralogy and Petrology, 58, 63-81. http://dx.doi.org/10.1007/BF00384>45

Pitcher, W. S. (1983). Granite type and tectonic environment. In K. Hsu (Ed.), Mountain Building Processes (pp. 19-40). London: Academic Press. 
Rahaman, M. A., Emofurieta, W. O., \& Caen-Vachette, M. (1983). The potassic granites of Igbeti area: Further evidence of of the polycyclic evolution of the Pan-African belt in southwestern Nigeria. Precambrian Research, 22, 75-92. http://dx.doi.org/10.1016/0301-9268(83)90059-1

Ukwang, E., \& Ekwueme, B. N. (2009). Geochemistry and geotectonic study of granitic rocks of southwest Obudu Plateau, southeastern Nigeria. Journal of Mining and Geology, 45, 73-82.

Van Breemen, O., Pidgeon, R.T., \& Bowden, P. (1977). Age and isotopic studies of some Pan-African granites from north-central Nigeria. Precambrian Research, $307-319$. http://dx.doi.org/10.1016/0301-9268(77)90001-8

Whalen, J. B., Currie, K. L., \& Chappell, B. W. (1987). A-type granites: geochemical characteristics, discrimination and petrogenesis. Contributions to mineralogy and Petrology, 95, 407-419. http://dx.doi.org/10.1007/BF00402202

White, A. J. R., \& Chappell, B. W. (1977). Ultrametamorphism and granitoid genesis. Tectonophysics, 43, 7-88. http://dx.doi.org/10.1016/0040-1951(77)90003-8

Wood, D. A., Tarney, J., Varet, J., Saunders, A. D., Bougault, H., Joron, J. L., ..., Cann, J. R. (1979). Geochemistry of basalts drilled in the North Atlantic by IPOD LEG 49: implications for mantle heterogeneity. Earth and Planetary Science Letters, 42, 77-97. http://dx.doi.org/10.1016/0012-821X(79)90192-4 